\title{
The Relationship Between Husband Support and Behavior of Pregnant Teenagers to Face Pregnancy During the Covid-19 Pandemic in Gombong, Kebumen, Indonesia
}

\author{
Wulan Rahmadhani ${ }^{*}$, Jipri Suyanto ${ }^{2}$, Than Kyaw Soe ${ }^{3}$, Siti Mutoharoh ${ }^{4}$ \\ ${ }^{1}$ Department of Midwifery, Sekolah Tinggi Ilmu Kesehatan Muhammadiyah Gombong, \\ Indonesia \\ 2Department of Public Health, Faculty of Health Science, Dehasen University, Indonesia \\ 3Water Sanitation and Hygiene, United Nations Children's Founds (UNICEF), Myanmar \\ ${ }^{4}$ Department of Midwifery, Sekolah Tinggi Ilmu Kesehatan Muhammadiyah Gombong, \\ Indonesia
}

*Corresponding author, email: wulan@stikesmuhgombong.ac.id

Received: 09/07/2021; published: 24/08/2021

\begin{abstract}
Background: Age influences pregnancy and childbirth. Pregnant women aged less than 20 years old or pregnant adolescents are not physically and mentally ready to cope with pregnancy or childbirth. The husband's support highly determines the health status of the mother. This research aimed to determine the relationship between husband support and the behavior of pregnant adolescents to face pregnancy during the COVID-19 pandemic in the Gombong District, Kebumen Regency. Methods: This study used a cross-sectional approach. The population was all pregnant women aged less than 20 years in the Gombong District, Kebumen Regency. It used a saturated sampling technique involving 256 people. Data were analyzed using univariate and bivariate analysis to answer the percentage and the Chi-Square test to answer the research hypothesis. Results: The study showed that $130(50.8 \%)$ husbands did not support the mothers, and $126(49.2 \%)$ husbands supported the mothers. The result also showed that $116(45.3 \%)$ of the pregnant women showed positive behavior, while140 $(54.7 \%)$ pregnant women showed negative behavior. The chi-square test found a $p$-value of 0.005 , which proved a significant relationship between the husband's support and the behavior of pregnant adolescents to overcome pregnancy during the covid-19 pandemic. Conclusion: Pregnant teenagers with husband support will prepare for pregnancy and childbirth programs more maturely to ensure the safety of both mother and fetus.
\end{abstract}

Keywords: Husband Support, Behavior of pregnant women, Teenagers, Covid-19

This is an open access article under the CC-BY-SA license.

\section{Introduction}

Pregnancy is one of the happiest moments for mothers, husbands, and their families [1]. Pregnant women will experience both physical and mental changes [2]. Thus, they need to consider their health highly [2]. In the first, second, and third trimesters, pregnant women experience different changes [3]. During the first thirteen weeks of pregnancy, pregnant women experience physical changes such as nausea, vomiting and are more sensitive to smells [4].

Age influences pregnancy and childbirth [5]. Mothers younger than 20 years old or pregnant adolescents are not physically and mentally ready to cope with pregnancy or childbirth [2]. Physically, their uterus and pelvis have not yet grown maximally, causing them to likely have difficulties in childbirth [2]. Further, mentally, they have not been ready to 
accept the duties and responsibilities of parents, so their self-care and baby care skills are doubted [6]. To achieve a healthy condition, as stated in the definition/limitation, it is also necessary to understand that a healthy reproductive period is between 20 to 35 years $[7,8]$.

Getting married aged less than 20 years will later affect the pregnancy [2]. The ideal age for women to get pregnant is 22-35 years as their physical condition is at optimum levels and peak of fertility [9]. For women who are pregnant at a young age, the function of their sexual and reproductive organs has not yet reached maturity [10]. Thus, they face preterm labor/miscarriage risks, bleeding after delivery, impaired fetal growth, and others [3]. Besides, at a very young age, mental conditions are also precarious [11]. Women who experience emotional problems during pregnancy can affect the process of fetal brain development $[12,13]$.

Covid-19 is an infectious disease caused by a recently discovered new type of coronavirus (SARS Cov-2) [14]. It is a new disease still being researched by health experts and scientific researchers [14]. Based on the latest data, pregnant women have the same risk of Covid-19 infection as other adults who are not pregnant [15]. Further, pregnant women with positive Covid-19 who experience no symptoms also have a high case rate of $13.8 \%$ in Indonesia [14]. Pregnancy and childbirth during the Covid-19 pandemic are more challenging than before [16]. However, a mother can go through the process comfortably and safely with the support of her husband [16].

Based on Survey Demografi Kesehatan Indonesia (SDKI) 2017 rate of pregnant at a young age increased by $4 \%$ of the population. Family support, especially the husband, during the wife's pregnancy is highly needed [17]. Family support means a relationship process in which one can access support and help to the family members [18]. In a family with a pregnant woman, the husband is expected to motivate, help, and accompany. The husband is also responsible for making her feeling comfortable and calm when there are problems in her pregnancy [19].

Previous studies on husband support for pregnant women have been conducted in some areas [20]. A study conducted showed that $98.1 \%$ of pregnant women did not receive husband support, and only $1.9 \%$ of pregnant women received it [21]. A similar study conducted in Semarang found that $56.7 \%$ of pregnant women did not receive husband support, and $43.3 \%$ received it [22]. Based on the explanation above, it can be concluded that family support influences the behavior of pregnant adolescents (less than 20 years old) who pay less attention to their pregnancy, including pregnancy control.

\section{Method}

This analytical correlation research used a cross-sectional approach. This research was conducted in the Gombong District, Kebumen Regency. The population of this study was all pregnant women aged less than 20 years in the Gombong District, Kebumen Regency. The research used a saturated sampling technique involving 256 people as samples. This study required the husbands to fill out the questionnaires that had been tested for validity within 30 respondents with $0.75-0.82$ and reliability with a Cronbach alpha value of 0.635 . The questionnaires were distributed online through the Google form link. The collected data were analyzed to find the percentage and answer the research hypothesis using the Chi-Square test.

\section{Results and Discussion}

\subsection{Results}

Based on the characteristics in Table 1, the age group of husbands of pregnant women in the Gombong District was 21-29 years old (46.9\%) with the senior high school education level (39.1\%) and majority occupation of farmers (35.2\%). Most of the husbands of pregnant women are Muslim (96.1\%) and Javanese (86\%). Otherwise, a total of $130(50.8 \%)$ of the husband of pregnant women did not provide support.

Table 2 shows that most of the wives or respondents were in the second trimester of pregnancy (14-28 weeks), with a total of 100 people (39.1\%). The majority of respondents were in their first pregnancy, with 189 people $(73.8 \%)$. Further, most pregnant women aged less than 20 years behave negatively, with a total of 140 people $(54.7 \%)$.

Table 3 shows that the husband did not support caused the negative behavior of pregnant women in dealing with pregnancy which was experienced by 104 respondents 
(81.3\%). Meanwhile, 96 respondents (75\%) received the husbands' support for the positive behavior. Based on Table 3, there was a difference in the pregnant women's behavior in dealing with pregnancy with and without husband support $(p<0.05)$. More details can be seen in Table 3.

Table 1. Characteristic of Husband of Pregnant Women

\begin{tabular}{lcc}
\hline \multicolumn{1}{c}{ Characteristics } & $\mathbf{n}$ & $\%$ \\
\hline Age & 78 & 30.5 \\
$<20$ & 120 & 46.9 \\
$21-29$ & 58 & 22.6 \\
$>30$ & & \\
Education & 33 & 12.9 \\
$\quad$ Elementary School & 33 & 12.9 \\
$\quad$ Junior High School & 100 & 39.1 \\
$\quad$ Senior High School & 90 & 35.1 \\
$\quad$ University & & \\
Occupation & 90 & 35.2 \\
$\quad$ Farmer & 56 & 21.9 \\
$\quad$ Private workers & 70 & 27.3 \\
$\quad$ Entrepreneur & 40 & 15.6 \\
$\quad$ Civil Servant & & \\
Religion & 246 & 96.1 \\
Islam & 10 & 3.9 \\
$\quad$ Christian & & \\
Enthicity & 220 & 86.0 \\
$\quad$ Javanese & 36 & 14.0 \\
$\quad$ Sundanese & & \\
Husband support & 126 & 59.2 \\
$\quad$ Supporting & 130 & \\
Not supporting & & \\
$\quad$ & & \\
\hline & &
\end{tabular}

Table 2. Characteristic of Pregnant Women Characteristics

$\mathbf{n} \%$

Age of pregnancy

Trimester I (0-13 weeks)

31.2

Trimester II (14-28 weeks)

39.1

Trimester III (29-39 weeks)

100

29.7

Parity

Primigravida

73.8

Multigravida

$189 \quad 73.8$

Pregnant women bevahior

Negative

67

26.2

Positive

140

54.7

116

45.3

Table 3. Bivariate Analysis Research

\begin{tabular}{cccccccc}
\hline & \multicolumn{2}{c}{ Pregnant Women Behavior } & \multicolumn{2}{c}{ Total } & \multirow{2}{*}{ p-value } \\
\cline { 2 - 6 } $\begin{array}{c}\text { Husband } \\
\text { Support }\end{array}$ & \multicolumn{2}{c}{$\begin{array}{c}\text { Negative } \\
\text { behavior }\end{array}$} & $\begin{array}{c}\text { Positive } \\
\text { behaviour }\end{array}$ & & & \\
\cline { 2 - 6 } & $\mathbf{n}$ & $\%$ & $\mathbf{n}$ & $\%$ & $\mathbf{n}$ & $\%$ & \\
\hline Not support & 104 & 81.3 & 24 & 18.8 & 128 & 100 & 0.005 \\
Support & 32 & 25 & 96 & 75 & 128 & 100 & \\
Total & 136 & 53.1 & 120 & 46.9 & 256 & 100 & \\
\hline
\end{tabular}

(continuity correction) $=8.03 p=0.005$ 


\subsection{Discussion}

A total of 130 respondents $(50.8 \%)$ did not receive support from the husband, while 126 respondents $(49.2 \%)$ received it. In Kebumen, the number of early married increased in pandemic Covid-19. Usually, they are the ones who have the nature of inconsistency between their knowledge, attitudes, and behavior. In this case, the husband is the wife's life partner (the father of the children) in which they have full responsibility in the family. They are highly demanded both as a breadwinner and supporters in various policies [17]. Research on husbands' support of young mothers' motivation in exclusive breastfeeding showed that most husbands (92.3\%) provided good support [23]. Good support from the husband motivates young mothers to behave well in practicing exclusive breastfeeding[19].

Husband's support is a form of social interaction in which there is a mutual giving and receiving relationship that places individuals involved in the social system, which will provide affection, attention, and a sense of attachment to both family and partner [17]. Husband support for wife represent 4 (four) components of support covering informational support, assessment, instrumental, and emotional support, which can be done by providing information on good pregnancy check-ups, being good listeners for the wife, paying attention to the nutritional needs of the wife, and infant, and encouraging wife in various conditions [20].

Furthermore, most pregnant women aged less than 20 years had negative behavior, with a total of 140 respondents (54.7\%). Meanwhile, 116 respondents $(45.3 \%)$ had positive behavior in dealing with pregnancy. The lack of behavior of pregnant women in protecting themselves from Covid-19 can be caused by a low level of self-awareness, bad habits, and the influence of the surrounding, which had terrible behavior patterns. Providing more comprehensive information for pregnant women during pregnancy visits related to how to maintain their health during pregnancy undergoing pregnancy during the Covid-19 pandemic, whether in the form of signs, symptoms, prognosis, treatment, access to fast and appropriate services, as well as proper health protocol procedures have to be applied in daily life.

Behavior is an individual's response or reaction to a stimulus (from outside) [24]. Pregnant women younger than 20 years showed an open behavior as their response to the stimulus of pregnancy was a natural action that can be observed by other people outside [25]. Therefore, the formed behavior was influenced by three factors of predisposing factors manifested in beliefs, values, and demographic variations; supporting factors manifested in the physical environment, including various kinds of facilities and infrastructure; and driving factors manifested in the attitudes and behavior of health workers or other officers, as well as reference groups of community behavior [24].

Different results in the research showed that as many as 8,237 husbands accompanied their wives in antenatal care and the birth process. Based on the research results above, differences in the behavior of pregnant women occurred due to different sociodemographics and characteristics of respondents. In this study, most of the respondents had negative behavior $(53.1 \%$ ) due to many factors such as young age (less than 20 years old), low level of education, and first pregnancy, no experience. Negative behavior lies in psychological feelings of shame, confusion, blaming others, and changing positive perceptions into negative ones [26]. Research also showed that there were $81.3 \%$ of husbands supported childbirth. There were $64.9 \%$ of husbands who accompanied their wives at delivery. There is a relationship between the husband's support and delivery assistance. It is expected that the husband can play an active role in assisting his wife so that it helps the smooth delivery process [27].

A total of 96 respondents (75\%) received the husband's support for positive behavior in coping with pregnancy, while 104 respondents (81.3\%) did not receive the husband's support for negative behavior in overcoming pregnancy. This study indicated a relationship between husband support and the behavior of pregnant women aged less than 20 years in dealing with pregnancy during the Covid-19 pandemic in the Gombong District. It meant that husband support was one of the factors affecting the behavior of pregnant women aged less than 20 years. Husband's support is vital for pregnant women under 20 years who are physically and psychologically unstable in dealing with pregnancy, as the closest person for them is the husband $[28,29]$. 
The results of this study are aligned with a study conducted at Puskesmas Nanggalo, Padang, in which there was a relationship between husband support and adherence to consumption of Fe tablets [30]. Hence, there was a relationship between husband support and anxiety of pregnant women overcoming the birth delivery of their first child during the third trimester in some birth delivery clinics in Purwokerto [17]. If the husband provided instrumental support in preparing the budget for the cost of birth delivery, the wife prepares for the baby's needs [11]. Husbands paid attention to nutritional needs by recommending pregnant women drinking milk and helping with household chores to giving them more time to rest, which finally makes them feel happy about their pregnancy [17]. Husbands tried to accompany the wife to have antenatal care regularly [20]. The emotional support by husbands in the form of praise and encouragement still made young pregnant women thought that pregnancy limited their activities, causing refuse to get pregnant as they still wanted to enjoy life without a child [20].

Concerning the support assessment, the husband feels happy for his wife's pregnancy and awaits the baby's birth by praying, which likely makes the wife feel more patient in dealing with pregnancy at a young age and more responsible for avoiding pregnancy problems [2]. Then, on information support, the husband knows that his wife is pregnant and tries to ensure the truth of her pregnancy [31]. The husband provides information on an excellent antenatal care provider, and the wife has antenatal care [18]. As the husband's knowledge about pregnancy is limited, the wife tried to find the needed information on her own by sharing about her pregnancy with other people in which she tried to open up to others [17]. The less support from husbands could affect the negative behavior of pregnant women aged less than 20 years old [2].

\section{Conclusion}

Based on the results of statistical tests, it can be concluded that there is a relationship between husband support and the behavior of pregnant women aged younger than 20 years in dealing with pregnancy during the Covid-19 pandemic. Further, more than half of pregnant women aged younger than 20 years have sufficient husband support. Health service providers are obliged to socialize the importance of support from the family and the husband. Husbands' support for pregnant women is necessary as the husband is the decision-maker in the family, particularly regarding pregnancy and childbirth.

\section{References}

1. E.McLean K. Men's Experiences of Pregnancy and Childbirth in Sierra Leone: Reexamining Definitions of "Male Partner Involvement." Soc Sci Med. 2020;265:113479. https://doi.org/10.1016/j.socscimed.2020.113479

2. Rahmadhani W, Laohasiriwong W. Gender of baby and postpartum depression among adolescent mothers in central Java, Indonesia. Int J Child Adolesc Heal. 2020;13(1 PG43-49). Available from: https://www.proquest.com/openview/db338900df1f9c1e8540314b1a00aa58/1.pdf?pqorigsite $=$ gscholar $\& \mathrm{cbl}=2034872$

3. Hasyati, Masni, Salmah AU, Tamar M. The Influence of Balanced Counseling Strategy on Mother Toward Use of Post Partum Family Planning. Enferm Clin. 2020;30. doi: https://doi.org/10.1016/j.enfcli.2019.10.116

4. Owusu-Addo SB, Owusu-Addo E, Morhe ESK. Health Information-Seeking Behaviours Among Pregnant Teenagers in Ejisu-Juaben Municipality, Ghana. Midwifery. 2016;41. doi: https://doi.org/10.1016/j.midw.2016.08.007

5. Rahmadhani W. Knowledge of Postpartum Mothers on Postpartum Care in Healthcare Centers in Kebumen. $J$ Ilm Kesehat Keperawatan. 2020;16[1]. doi: https://doi.org/10.26753/jikk.v16i1.379

6. Queiroz MVO, Menezes GMD, Silva TJP, Brasil EGM, Silva RM da. Pregnant Teenagers' Group: Contributions to Prenatal Care. Rev Gauch Enferm. 2017;37(spe). doi: http://dx.doi.org/10.1590/1983- 1447.2016.esp.2016-0029

7. Lockwood Estrin G, Ryan EG, Trevillion K, Demilew J, Bick D, Pickles A, et al. Young Pregnant Women and Risk for Mental Disorders: Findings From An Early Pregnancy Cohort. BJPsych Open. 2019;5[2]:1-7. https://doi.org/10.1192/bjo.2019.6

8. Howard LM, Khalifeh H. Perinatal Mental Health: A Review of Progress and Challenges. 
World Psychiatry. 2020;19[3]:313-27. https://doi.org/10.1002/wps.20769

9. Brummelte S, Galea LAM. Postpartum Depression: Etiology, Treatment and Consequences for Maternal Care. Horm Behav. 2016; doi: https://doi.org/10.1016/j.yhbeh.2015.08.008

10. Jantacumma N, Powwattana A, Lagampan S, Chansatitporn N. Predictive Model of Quality of Life Among Thai Pregnant Teenagers. Pacific Rim Int J Nurs Res. 2018;22[1]. Available from: https://he02.tci-thaijo.org/index.php/PRIJNR/article/view/86391

11. Aryanti A, Karneli K, Sella. Hubungan Dukungan Suami pada Ibu Hamil Terhadap Kunjungan Antenatal Care (ANC) di BPM Soraya Palembang. Cendekia Med. 2020;5[2]. doi: https://doi.org/10.52235/cendekiamedika.v5i2.68

12. Chawla D, Bernard Fuemmeler, Sara E. Benjamin-Neelon, Hoyo C, Murphy S, Daniels JL. Early Prenatal Vitamin D Concentrations and Social-emotional Development in Infants. J Matern Neonatal Med. 2019;32[9]:1441-8. https://doi.org/10.1080/14767058.2017.1408065

13. Lautarescuab A, C.Craigac M, Glover V. Chapter Two - Prenatal Stress: Effects on Fetal and Child Brain Development. Int Rev Neurobiol. 2020;150:17-40. doi: https://doi.org/10.1016/bs.irn.2019.11.002

14. World Health Organization. WHO COVID-19 Case Definition. World Health Organization. 2020. WHO/2019-nCoV/Surveillance_Case_Definition/2020.2

15. González-de la Torre H, Rodríguez-Rodríguez R, Martín-Martínez A. Recommendations and Practical Management of Pregnant Women with COVID-19: A scoping review. Enferm Clin. 2021;31. doi: https://doi.org/10.1016/j.enfcli.2020.05.009

16. Gao YJ, Ye L, Zhang JS, Yin YX, Liu M, Yu HB, et al. Clinical Features and Outcomes of Pregnant Women with COVID-19: A Systematic Review and Meta-Analysis. BMC Infect Dis. 2020;20[1]. https://doi.org/10.1186/s12879-020-05274-2

17. Farida L, Kurniawati D, Juliningrum PP. Hubungan Dukungan Suami dengan Kesiapan Persalinan pada Ibu Hamil Usia Remaja di Sukowono, Jember. Pustaka Kesehat. 2019;7[2]. DOI: https://doi.org/10.19184/pk.v7i2.19125

18. Siregar NY, Kias CF, Nurfatimah N, Noya F, Longgupa LW, Entoh C, et al. Tingkat Kecemasan Ibu Hamil Trimester III dalam Menghadapi Persalinan. J Bidan Cerdas. 2021;3[1]. doi: https://doi.org/10.33860/jbc.v3i1.131

19. Saudah N. Relationship Husband Support of Anemia Management with Incidence Anemia in Pregnancy. Int $J$ Nurs MIDWIFERY Sci. 2020;4[3]. doi: https://doi.org/10.29082/IJNMS/2020/Vol4/lss3/324

20. Hanifah A, Pratomo H, Hoang G. Husband's Support for Their Wives in Antenatal Care Visit. Kesmas. 2018;13[1]. doi: http://dx.doi.org/10.21109/kesmas.v13i1.1565

21. Woldetsadik AM, Ayele AN, Roba AE, Haile GF, Mubashir K. Prevalence of Common Mental Disorder and Associated Factors Among Pregnant Women in South-East Ethiopia, 2017: A Community Based Cross-Sectional Study. Reprod Health. 2019;16[1]:1-8. doi: https://doi.org/10.1186/s12978-019-0834-2

22. Mulyanti L, Chafidoh C, Damayanti FN. Gambaran Pelaksanaan Informed Consent Bidan Praktik Mandiri (BPM) Dalam Pelayanan Kebidanan di Kota Semarang. Indones J Kebidanan. 2017;1[2]. doi: http://dx.doi.org/10.26751/ijb.v1i2.380

23. Nakajima K, Usui A, Hayakawa Y. Feelings of Older Japanese Primiparous Couples and Satisfaction of Older Primiparous Wives with Their Husbands' Support During Pregnancy: Focus on The Perceptions of Pregnant Couples. Nurs Open. 2020;7[5]. doi: 10.1002/nop2.509

24. M.Moscarello J, A.Hartley C. Agency and the Calibration of Motivated Behavior. Trends Cogn Sci. 2017;21[10]:725-35. doi: https://doi.org/10.1016/j.tics.2017.06.008

25. Frederiksen MSc LE, Ernst AM, Brix NM, Lauridsen B, BSc LL, Roos LM, et al. Risk of Adverse Pregnancy Outcomes at Advanced Maternal Age. Obstet Gynecol. 2018;131[3]:457-63. doi: 10.1097/AOG.0000000000002504

26. Rumaseuw R, Berliana SM, Nursalam N, Efendi F, Pradanie R, Rachmawati PD, et al. Factors Affecting Husband Participation in Antenatal Care Attendance and Delivery. IOP Conf Ser Earth Environ Sci. 2018;116[1]. doi :10.1088/1755-1315/116/1/012012

27. Satrianegera MF, Hadju V, Kurniati Y. The Importance of Husband Support During Childbirth in Indonesia. Al-Sihah Public Heal Sci J. 2021;13[1]:74. doi: https://doi.org/10.24252/al-sihah.v13i1.21398 
28. Nsemo AD, Ojong IN, Agambire R, Afoakwah G. Pregnant Teenagers' Perception and Access to Focused Ante Natal Care Services in A Ghanaian Government Hospital. African $J$ Biomed Res. 2020;23[2]. doi: https://www.ajol.info/index.php/ajbr/article/view/202189

29. Eddy BP, Fife ST. Active Husband Involvement During Pregnancy: A Grounded Theory. Int J Appl Fam Sci. 2020;19. https://doi.org/10.1111/fare.12486

30. Omenge Obwoge R, Okere A, Chamia L, Nduku J, Koech H, Muruthi C, et al. Health Related Challenges Among Pregnant Teenagers Attending Narok County Hospital, Narok County. Int J Gastroenterol. 2019;3[2]. doi: 10.11648/j.ijg.20190302.12

31. Rahmadhani W, Asti AD. Peningkatan Kesehatan Reproduksi Remaja Melalui Pendampingan Kelompok Terapeutik di Desa Indrosari, Kecamatan Bulus Pesantren, Kebumen. J Empati (Edukasi Masyarakat, Pengabdi dan Bakti). 2020;1[1]. doi: https://doi.org/10.26753/empati.v1i1.425 